\title{
PENYELENGGARAAN PELAYANAN KELUARGA BERENCANA DALAM JAMINAN KESEHATAN NASIONAL
}

\author{
Oktriyanto*) \\ Badan Kependudukan dan Keluarga Berencana (BKKBN) Pusat, Jakarta Timur 13650, Indonesia
}

*)E-mail:oktriyanto@yahoo.com

\begin{abstract}
Abstrak
Program Jaminan Kesehatan Nasional (JKN) diselenggarakan dengan tujuan agar setiap peserta memperoleh pemeliharaan dan perlindungan dalam memenuhi kebutuhan dasar kesehatan termasuk pelayanan Keluarga Berencana (KB). Tujuan dari penelitian ini adalah untuk mengetahui gambaran penyelenggaraan pelayanan KB dalam JKN. Penelitian ini menggunakan desain cross sectional. Responden penelitian ini terdiri dari responden dari keluarga, responden dari institusi, dan responden dari tempat dan tenaga kesehatan pemberi layanan KB di Provinsi Lampung (Kota Bandar Lampung dan Kabupaten Pesawaran), Provinsi Jawa Barat (Kota Bandung dan Kabupaten Purwakarta), Provinsi Kalimantan Tengah (Kota Palangka Raya dan Kabupaten Pulang Pisau), dan Provinsi Nusa Tenggara Timur (Kota Kupang dan Kabupaten Kupang). Responden dari keluarga melibatkan 240 wanita dari Pasangan Usia Subur (PUS), dengan jumlah 30 orang di masing-masing lokasi penelitian. Hasil penelitian menunjukkan bahwa secara umum kesiapan institusi untuk melaksanakan pelayanan KB dalam JKN belum maksimal, sistem informasi Fasilitas Kesehatan antara BKKBN dan BPJS Kesehatan belum terpadu, dan pengetahuan masyarakat tentang JKN relatif tinggi tetapi kepemilikan kartu BPJS Kesehatan masih rendah.
\end{abstract}

Kata kunci: keluarga berencana, fasilitas kesehatan, BPJS Kesehatan, jaminan kesehatan nasional

\section{Operation of Family Planning Services in The National Health Insurance}

\begin{abstract}
The National Health Insurance Program was organized with the aim that each participant obtain maintenance and protection in fulfilling the basic needs of health, including family planning services. The purpose of this study is to describe the implementation of family planning services in The National Health Insurance Program. This study used cross sectional design. The respondents of this study are from family, institutions and family planning service providers in the Province of Lampung (Bandar Lampung and Pesawaran), West Java (Bandung and Purwakarta), Central Kalimantan (Palangkaraya and Pulang Pisau), and East Nusa Tenggara (Kupang city and Kupang district). Respondent of familiy involve 240 women of couples of childbearing age (PUS); which is involved 30 people in each study site. Generally, the result showed that the readiness of institutions in implementation of the family planning services in the national health insurance were not maximized, health facility information system between BKKBN and BPJS Kesehatan (Healthcare and Social Security Agency) had not been integrated, and the community's knowledge about The National Health Insurance Program was relative high, but BPJS Kesehatan (Healthcare and Social Security Agency) card ownership was still low.
\end{abstract}

Keywords: family planning, health facility, BPJS Kesehatan (Healthcare and Social Security Agency), the national health insurance

\section{PENDAHULUAN}

Pemerintah merupakan organisasi yang bertanggung jawab menyelenggarakan pelayanan kesehatan yang menyeluruh, bermutu, dan terjangkau untuk semua lapisan masyarakat (Djunawan \& Haksama, 2015; Hartati, 2015; Endartiwi, 2015; Yandrizal \& Suryani, 2015). Sejak 1 Januari 2014, jaminan sosial bidang kesehatan diselenggarakan oleh suatu badan publik yaitu Badan Penyelenggara Jaminan Sosial (BPJS) Kesehatan, yang merupakan transformasi dari
PT Askes (Persero). Jaminan kesehatan yang dimaksud merupakan perlindungan dalam pemeliharaan kesehatan yang memenuhi kebutuhan dasar kesehatan bagi mereka yang membayar iuran atau iurannya dibayarkan oleh pemerintah. Pada tahun 2019, Jaminan Kesehatan Nasional diharapkan akan melayani seluruh penduduk Indonesia agar dapat terlindungi dengan asuransi sesuai tahapan kepesertaan.

Setiap peserta JKN berhak memperoleh manfaat jaminan kesehatan yang bersifat 
pelayanan kesehatan perorangan, mencakup pelayanan promotif, preventif, kuratif, dan rehabilitatif termasuk pelayanan obat dan bahan medis habis pakai sesuai dengan kebutuhan medis yang diperlukan. Peraturan Presiden RI Nomor 12 Tahun 2013 tentang Jaminan Kesehatan menyebutkan bahwa Keluarga Berencana (KB) merupakan salah satu manfaat pelayanan promotif dan preventif selain penyuluhan kesehatan perorangan, imunisasi dasar, dan skrining kesehatan. Pelayanan KB meliputi konseling, kontrasepsi dasar, vasektomi, dan tubektomi.

Institusi penyelenggara pelayanan KB dalam JKN untuk melaksanakan tugasnya memiliki acuan yaitu perjanjian kerjasama antara BKKBN dengan PT Askes (Persero) Nomor 363/KSM/G2/2013 dan Nomor 0487/KTR/1213 tentang Penyelenggaraan Pelayanan Keluarga Berencana pada Jaminan Kesehatan Nasional, yang diperbarui dengan Perjanjian Kerjasama antara BKKBN dengan BPJS Kesehatan Nomor 83/KSM/G2/2014 dan Nomor 0199/KTR/0314 perihal yang sama. Selain itu, penyelenggaraan pelayanan KB dalam JKN mengacu pada Peraturan Kepala BKKBN Nomor 185/PER/E1/2014 tentang Pedoman Penyelenggaraan Pelayanan KB dalam JKN. Selanjutnya, dalam rangka pemantapan Penyelenggaraan Pelayanan KB dalam JKN maka diperlukan suatu pengorganisasian dalam bentuk Kelompok Kerja (POKJA) Keluarga Berencana JKN. POKJA tersebut dibentuk secara berjenjang, mulai dari tingkat pusat, provinsi, kabupaten/kota, kecamatan sampai tingkat desa/kelurahan.

Pedoman Penyelenggaraan Pelayanan KB dalam JKN menjelaskan pendataan Fasilitas Kesehatan (Faskes) yang melayani KB dalam JKN dilakukan dengan menggunakan Formulir Pendaftaran Faskes KB (K/0/KB/13). Faskes KB yang sudah memiliki Perjanjian Kerja Sama (PKS) dengan BPJS Kesehatan namun belum teregistrasi dalam SIM BKKBN maka Perwakilan BKKBN Provinsi dan/atau Satuan Kerja Perangkat Daerah (SKPD) KB tingkat Kabupaten dan Kota harus segera melakukan pemberian nomor registrasi kepada Faskes KB tersebut menggunakan Formulir $\mathrm{K} / 0 / \mathrm{KB} / 13$ yang berkoordinasi dengan Dinas Kesehatan setempat. Pemutakhiran data Faskes yang melayani KB dalam JKN dapat dilakukan setiap saat ada pembentukan Faskes KB baru yang telah memiliki PKS dengan BPJS Kesehatan yang akan dilaporkan setiap enam bulan. Klasifikasi Faskes KB terdiri dari Faskes KB sederhana, lengkap, sempurna, dan paripurna.
Penelitian mengenai Program JKN sudah banyak dilakukan, seperti penelitian yang dilakukan oleh Amalina et al. (2015) yang menemukan bahwa tingkat pengetahuan JKN pada peserta Penerima Bantuan luran (PBI) diperoleh sebanyak 74,0 persen responden yang memiliki pengetahuan kurang, sedangkan peserta $\mathrm{PBI}$ yang memiliki pengetahuan baik hanya sebanyak 8,0 persen. Pada peserta bukan PBI JKN terdapat 3 persen responden dengan pengetahuan kurang, sedangkan responden yang memiliki pengetahuan baik sebanyak 80,0 persen. Hal ini berarti tingkat pengetahuan pada peserta $\mathrm{PBI}$ mayoritas masih kurang, sedangkan pada peserta bukan PBI sebaliknya. Berdasarkan tingkat pengetahuan terhadap program JKN, hasil penelitian dari Sastradimulya et al. (2015) ditemukan bahwa sebanyak 45 orang $(37,5 \%)$ memiliki tingkat pengetahuan dalam kategori baik. Selanjutnya, berdasarkan status kepesertaan, hasil penelitian dari Sastradimulya et al., (2015) ditemukan sebanyak 56,7 persen responden telah mengikuti program JKN. Hal ini dikarenakan responden di Puskesmas Majalaya telah mengetahui informasi terkait JKN melalui program Jamkesmas dan sosialisasi oleh pihak BPJS di Puskesmas Majalaya.

Namun demikian masih sedikit sekali penelitian yang melihat Program JKN dari sisi pelayanan KB. Penelitian sebelumnya lebih banyak melihat Proram JKN dari sisi pelayanan kesehatan secara umum. Penelitian ini menjadi penting dilakukan untuk dapat mengetahui gambaran penyelenggaraan pelayanan KB dalam JKN. Secara khusus tujuan penelitian ini adalah: 1) mengetahui kesiapan institusi penyelenggara pelayanan KB dalam JKN (BKKBN, SKPD KB kabupaten/kota, BPJS Kesehatan dan Dinas Kesehatan); 2) mengetahui jumlah fasilitas kesehatan terdaftar dalam K/0/KB yang sudah bekerja sama dengan BPJS Kesehatan; 3) mengetahui jumlah fasilitas kesehatan bekerja sama dengan BPJS Kesehatan yang terdaftar dalam K/O/KB; dan 4) mengetahui pengetahuan dan kepesertaan masyarakat dalam layanan BPJS Kesehatan.

\section{METODE}

Penelitian ini menggunakan desain cross sectional study. Lokasi penelitian dipilih secara purposive dengan pertimbangan keterwakilan wilayah Indonesia yang terdiri dari Indonesia bagian Barat, Indonesia bagian Tengah dan Indonesia bagian Timur. Pemilihan kabupaten/kota dilakukan dengan sengaja 
dengan pertimbangan kabupaten/kota yang banyak memiliki kesehatan dan penyedia layanan KB. Wilayah Indonesia bagian Barat dipilih Provinsi Lampung (Kota Bandar Lampung, Kabupaten Pesawaran), dan Provinsi Jawa Barat (Kota Bandung, Kabupaten Purwakarta). Selanjutnya, Indonesia bagian tengah diwakili oleh Provinsi Kalimantan Tengah (Kota Palangka Raya, Kabupaten Pulang Pisau). Sementara itu, Indonesia bagian Timur dipilih Provinsi Nusa Tenggara Timur (Kota Kupang dan Kabupaten Kupang). Pelaksanaan pengumpulan data dilakukan pada tanggal 5 hingga 30 Agustus 2015.

Responden dalam penelitian ini terdiri dari responden dari keluarga, responden dari institusi, dan responden dari tempat dan tenaga pemberi layanan KB. Responden dari keluarga adalah wanita dari pasangan usia subur umur 15-49 tahun di kabupaten/kota terpilih. Masing-masing kabupaten/ kota dipilih 30 responden sehingga jumlah responden di 8 (delapan) kabupaten/ kota adalah 240 responden.

Selanjutnya responden institusi berasal penyelenggara program $\mathrm{KB}$, yang terdiri dari a) Perwakilan BKKBN Provinsi (Kepala Perwakilan BKKBN Provinsi, Kabid KB, dan Kabid Adpin); b) Kantor Cabang BPJS Kesehatan dan Kantor Layanan Operasional Kabupaten (KLOK) BPJS Kesehatan; c) Dinas Kesehatan Provinsi dan Dinas Kesehatan Kabupaten/Kota; d) Satuan Kerja Perangkat Daerah (SKPD) KB Kabupaten/Kota (Kepala SKPD KB, Kabid KB); dan e) PPLKB/PLKB.

Sementara itu, responden yang berasal dari tempat dan tenaga pemberi layanan KB terdiri dari: a) rumah sakir yang sudah dan belum bekerja sama dengan BPJS Kesehatan; b) puskesmas; c) klinik yang sudah dan belum bekerja sama dengan BPJS Kesehatan; d) dokter perorangan yang sudah dan belum bekerja sama dengan BPJS Kesehatan; dan e) bidan praktek mandiri yang sudah dan belum menjadi jejaring BPJS Kesehatan.

Data yang dikumpulkan dalam penelitian ini dibedakan berdasarkan respondennya. Data yang dikumpulkan dari responden keluarga terdiri dari karakteristik responden, pengetahuan dan praktek KB, kualitas pelayanan KB. Data yang dikumpulkan dari responden institusi adalah kebijakan, fasilitas kesehatan $\mathrm{KB} / \mathrm{Klinik} \mathrm{KB}$, pasangan usia subur KPS dan KS-1, dukungan dana, tenaga dan sarana prasarana, dan pelaksanaan pelayanan
KB. Sementara itu, data yang dikumpulkan dari responden tempat dan tenaga pemberi layanan KB terdiri dari proses kerja sama fasilitas kesehatan dengan BPJS, pelaksanaan pelayanan kesehatan KB dalam JKN, pelaksanaan mekanisme klaim pelayanan KB dalam JKN, dan alasan belum bekerja sama dengan BPJS

Data yang telah diperoleh, khususnya data kuantitatif dari responden yang mewakili keluarga, diolah melalui proses pengeditan (editing), pengkodean (coding), pemasukan data (entering), cleaning dan analisis data menggunakan program komputer berupa Microsoft Excel dan SPSS. Sementara itu, data kualitatif diolah dari transkrip hasil wawancara mendalam.

\section{HASIL}

\section{Kesiapan Institusi Penyelenggara Layanan KB}

Institusi penyelenggara pelayanan KB dalam JKN terdiri dari BKKBN, Dinas Kesehatan, dan BPJS Kesehatan termasuk tempat dan tenaga pemberi pelayanan KB seperti Rumah Sakit, Puskesmas, Klinik, Dokter Perorangan, dan Bidan Praktek Mandiri. Kesiapan Institusi Penyelenggara Pelayanan KB dalam JKN mengacu pada perjanjian kerjasama antara BKKBN dengan PT Askes (Persero) nomor 363/KSM/G2/2013 dan nomor 0487/KTR/ 1213 , kemudian diperbarui dengan perjanjian kerjasama antara BKKBN dan BPJS Kesehatan nomor 83/KSM/G2/2014 dan nomor 0199/KTR/0314 tanggal 28 Maret 2014. Pada perjanjian kerjasama tersebut, telah disepakati bahwa ada 7 (tujuh) tugas dan tanggung jawab BKKBN dan ada 4 (empat) tugas dan tanggung jawab BPJS Kesehatan yang harus dilaksanakan terkait penyelenggaraan pelayanan KB dalam JKN (Tabel 1). Tiga dari empat tugas dan tanggung jawab yang harus dilaksanakan BPJS Kesehatan yaitu: 1) memberi informasi data fasilitas kesehatan (Faskes), 2) melakukan sosialisasi pelayanan $\mathrm{KB}$ dalam JKN, dan 3) melaksanakan bimbingan teknis, pemantauan, pengawasan dan evaluasi Program KB dalam JKN. Ketiga tugas dan tanggung tersebut dilaksanakan BPJS Kesehatan bersama dengan BKKBN. Sementar itu, satu tugas dan tanggung jawab khusus BPJS Kesehatan yaitu menyediakan anggaran pelayanan KB pada setiap Faskes.

Tugas pertama bagi BKKBN adalah memberikan informasi dan rekomendasi 
kepada BPJS Kesehatan tentang Faskes yang telah memenuhi kriteria dan persyaratan untuk memberikan pelayanan KB di fasilitas kesehatan milik pemerintah dan swasta kepada yang telah terdaftar pada BPJS Kesehatan. Tugas memberikan informasi data Faskes tidak hanya bagi BKKBN, tetapi juga bagi BPJS Kesehatan. BKKBN berkewajiban memberikan data Faskes yang terdaftar dalam K/0/KB-BKKBN ke BPJS Kesehatan dan sebaliknya, BPJS Kesehatan memberikan data Faskes yang bekerja sama dengan BPJS Kesehatan ke BKKBN.

Hasil penelitian menunjukkan bahwa pemberian informasi data Faskes yang bekerja sama dengan BPJS Kesehatan dan data Faskes yang terdaftar dalam K/0/KB-BKKBN belum baik. Pemberian informasi data Faskes hanya terjadi antara perwakilan BKKBN provinsi dengan Kantor Cabang BPJS Kesehatan yang ada di ibukota provinsi. Sementara itu, antar SKPD KB dengan BPJS
Kesehatan tidak terjadi saling tukar informasi data Faskes.

Tugas kedua BKKBN adalah menggerakkan secara berjenjang mulai dari perwakilan BKKBN provinsi dan SKPD bidang KB kabupaten/kota untuk meningkatkan kerjasama dan koordinasi dengan Dinas Kesehatan provinsi dan kabupaten/kota, dan Puskesmas di wilayah kerjanya dalam pelaksanaan program KB melalui pertemuan berkala, bimbingan teknis, dan supervisi terpadu.

Pada pemenuhan tugas kedua, hasil penelitian menunjukkan bahwa pertemuan lintas sektor antara BKKBN maupun SKPD KB dengan Dinas Kesehatan di empat provinsi lokasi penelitian sudah sering dilakukan terutama pada saat akan melaksanakan pelayanan KB mobile. Koordinasi lintas sektor tidak ada perbedaan sebelum dan sesudah era JKN.

Tabel 1 Tugas dan tanggung jawab BKKBN dan BPJS Kesehatan berdasarkan perjanjian kerjasama Nomor 83/KSM/G2/2014 dan Nomor 0199/KTR/0314 Tugas BKKBN

1. Memberikan informasi dan rekomendasi kepada BPJS Kesehatan tentang fasilitas kesehatan yang telah memenuhi kriteria dan persyaratan untuk memberikan pelayanan KB di fasilitas kesehatan baik milik pemerintah maupun swasta kepada yang telah terdaftar pada BPJS Kesehatan.

2. Menggerakkan secara berjenjang mulai dari perwakilan BKKBN provinsi dan SKPD bidang keluarga berencana kabupaten/kota untuk meningkatkan kerjasama dan koordinasi dengan dinas kesehatan provinsi, dinas kesehatan kabupaten/kota, dan puskesmas di wilayah kerjanya dalam pelaksanaan program keluarga berencana melalui pertemuan berkala, bimbingan teknis, dan supervisi terpadu.

3. Menyediakan dan mendistribusikan:

a) Materi komunikasi, informasi, dan edukasi untuk penggerakan pelayanan KB dan Kesehatan Reproduksi (KR) ke fasilitas pelayanan yang bekerja sama dengan BPJS Kesehatan.

b) Sarana penunjang pelayanan kontrasepsi ke fasilitas pelayanan yang bekerja sama dengan BPJS Kesehatan.

c) Menjamin ketersediaan alat dan obat kontrasepsi (alkon) sesuai dengan kebutuhan pelayanan KB ke seluruh fasilitas pelayanan yang teregistrasi dan bekerja sama dengan BPJS Kesehatan.

4. Merencanakan lokus penggerakan pelayanan KB mobile sesuai dengan penetapan Pasangan Usia Subur (PUS), yang berkoordinasi dengan Dinas Kesehatan setempat.

5. Melakukan pelatihan teknis medis pelayanan KB bagi dokter dan bidan serta pelatihan non teknis medis bagi petugas pada fasilitas pelayanan yang bekerja sama dengan BPJS Kesehatan.

6. Melakukan sosialisasi pelayanan KB dalam JKN.

7. Melaksanakan bimbingan teknis, pemantauan, pengawasan, dan evaluasi Program KB dalam JKN. Tugas BPJS Kesehatan

1. Memberikan informasi kepada BKKBN tentang fasilitas kesehatan baik milik pemerintah maupun swasta yang telah bekerja sama dengan BPJS Kesehatan.

2. Menyediakan anggaran pelayanan KB pada setiap fasilitas kesehatan, sesuai dengan peraturan yang berlaku.

3. Melakukan sosialisasi pelayanan KB dalam JKN.

4. Melaksanakan bimbingan teknis, pemantauan, pengawasan dan evaluasi Program KB dalam JKN. 
Sementara itu, tugas ketiga bagi BKKBN adalah menyediakan dan mendistribusikan materi komunikasi, informasi dan edukasi (KIE) untuk penggerakan pelayanan KB dan Kesehatan Reproduksi (KR) ke fasilitas pelayanan yang bekerja sama dengan BPJS Kesehatan; menyediakan dan mendistribusikan sarana penunjang pelayanan kontrasepsi ke fasilitas pelayanan yang bekerja sama dengan BPJS Kesehatan; dan menjamin ketersediaan alat dan obat kontrasepsi (alkon) sesuai dengan kebutuhan pelayanan KB ke seluruh fasilitas pelayanan yang teregistrasi dan bekerja sama dengan BPJS Kesehatan.

Pada pemenuhan tugas ketiga, hasil penelitian menunjukkan bahwa materi KIE masih bersifat umum, belum ada secara khusus mengenai pelayanan KB dalam JKN. Sarana penunjang pelayanan KB yang diberikan ke Faskes berupa konseling kit, buku Panduan Praktis Pelayanan Kontrasepsi (BP3K), tensimeter, timbangan berat badan, obgyn bed, IUD kit, implan removal kit, VTP kit, dan minilaparatomi kit/laparoskopi. Alkon yang diberikan ke Faskes terdiri dari pil, suntikan, implan, dan IUD. Saat penelitian berlangsung, terjadi kelangkaan kontrasepsi terutama suntik KB. $\mathrm{Hal}$ ini dikarenakan keterlambatan pengadaan suntik KB dari BKKBN Pusat.

Tugas keempat bagi BKKBN adalah merencanakan lokus penggerakan pelayanan KB mobile sesuai dengan penetapan Pasangan Usia Subur (PUS), yang berkoordinasi dengan Dinas Kesehatan. Buku "Materi Kualitas Pelayanan KB Mobile" menyebutkan pelayanan KB mobile diprioritaskan pada daerah yang secara geografis sulit dijangkau dan aksesibilitas ke pelayanan statis sangat rendah dan minimal, diantaranya sarana kurang dan tenaga kesehatan yang terbatas. Hasil penelitian menunjukkan bahwa pelayanan KB mobile di empat provinsi wilayah penelitian melalui bakti sosial dilaksanakan berdasarkan momentum. Pelayanan KB yang diberikan terutama pelayanan KB metode kontrasepsi jangka panjang (MOP, IUD, implan) kecuali MOW. Pada era JKN, pelayanan KB mobile, dari empat provinsi lokasi penelitian, hanya Provinsi Jawa Barat yang melakukan pemilahan data peserta JKN dan bukan peserta JKN.

Tugas kelima bagi BKKBN adalah melakukan pelatihan teknis medis pelayanan KB bagi dokter dan bidan serta pelatihan non teknis medis bagi petugas di fasilitas pelayanan yang bekerja sama dengan BPJS Kesehatan. Hasil penelitian menunjukkan bahwa dari empat provinsi wilayah penelitian sudah melakukan pelatihan teknis medis maupun non teknis medis. Pelaksanaan pelatihan tersebut semua telah dilaporkan ke BKKBN Pusat melalui Sistem Informasi Diklat Kependudukan dan KB (SIDIKA) secara online.

Jenis pelatihan teknis medis dan non teknis medis di Provinsi Lampung hingga Bulan Juli 2015 antara lain: pelatihan budaya kerja; pelatihan manajemen program KKB; pelatihan dasar demografi; pelatihan KIP-Konseling KB dan $\mathrm{KR}$; pelatihan konselor sebaya program Genre; pelatihan manajemen program KKB; pelatihan pencatatan dan pelaporan program KKB; pelatihan pendidik sebaya Program Genre; pelatihan Pengelolaan Pelayanan Keluarga Sejahtera (PPKS); pelatihan stratifikasi pengadaan barang dan jasa; serta pelatihan CTU, IUD dan implan. Jenis pelatihan teknis medis dan non teknis medis di Provinsi Jawa Barat hingga Bulan Juli 2015 antara lain: pelatihan manajemen program KKB; TOT pelatihan BKL; TOT pelatihan pendataan keluarga program KKB (MDK); diklat calon peneliti; pelatihan BKL; pelatihan KIP-konseling dengan menggunakan ABPK; pelatihan MOW; pelatihan pengelola PPKS; pelatihan pengelolaan operasional lini lapangan; pelatihan rancang bangun kurikulum pelatihan; pelatihan refreshing program KKB; pelatihan sertifikasi pengadaan barang dan jasa; dan pelatihan IUD dan implan.

Jenis pelatihan teknis medis dan non teknis medis di Provinsi Kalimantan Tengah hingga Bulan Juli 2015 antara lain: pelatihan KIP konseling KBKR; pelatihan pembangunan berwawasan kependudukan; pelatihan pencatatan dan pelaporan program KKB; pelatihan pendataan keluarga program KKB (MD); pelatihan refreshing program KKB; pelatihan advokasi dan KIE program KKB. Selanjutnya, jenis pelatihan teknis medis dan non teknis medis di Provinsi Nusa Tenggara Timur hingga Bulan Juli 2015 antara lain: pelatihan advokasi dan KIE program KKB; TOT pelatihan pendataan keluarga program $\mathrm{KKB}(\mathrm{MDK})$; diklat fungsional dasar bagi calon PKB; pelatihan KIP-konseling dengan menggunakan $\mathrm{ABPK}$; pelatihan pencatatan dan pelaporan KKB; dan pelatihan program Genre.

Tugas keenam bagi BKKBN adalah melakukan sosialisasi pelayanan KB dalam JKN. Tugas ini juga merupakan tugas bagi BPJS Kesehatan. Hasil penelitian menunjukkan bahwa semua 
Provinsi yang menjadi lokasi penelitian sudah melakukan sosialisasi pelayanan KB dalam $\mathrm{JKN}$, namun dalam intensitas yang berbeda. Selain itu, saat sosialisasi masih terfokus pada pelayanan kesehatan secara umum, belum terfokus pada pelayanan KB dalam JKN.

Tugas ketujuh bagi BKKBN adalah melaksanakan bimbingan teknis, pemantauan, pengawasan, dan evaluasi Program KB dalam JKN. Hasil penelitian menunjukkan bahwa semua lokasi penelitian sudah melakukan bimbingan teknis, pemantauan, pengawasan, dan evaluasi program KB. Hanya saja kegiatan yang dilakukan merupakan kegiatan rutinitas tahunan dan tidak ada perbedaan sebelum maupun sesudah adanya JKN. Tugas ini juga merupakan tugas yang harus dilakukan oleh BPJS Kesehatan. Namun dari keempat provinsi, hanya Provinsi Lampung yang sudah melakukan evaluasi Program KB dalam JKN. Evaluasi yang dilakukan oleh Kantor Cabang BPJS Kesehatan Kota Bandar Lampung memperoleh informasi mengenai klaim KB yang telah dibayarkan oleh BPJS Kesehatan dan kendala yang terjadi di lapangan terkait pelayanan KB dalam JKN. Selanjutnya, dalam rangka pemantapan penyelenggaraan pelayanan KB dalam JKN, sangat penting dibentuknya kelompok kerja (POKJA) KB dalam JKN. Hasil penelitian menunjukkan bahwa, semua wilayah penelitian belum terbentuk POKJA KB dalam JKN. Lebih lanjut buku "Pedoman Penyelenggaraan Pelayanan KB dalam JKN" yang isi di dalamnya terdapat tugas dan fungsi POKJA KB JKN dan susunan organisasi POKJA KB JKN, belum dimiliki oleh semua perwakilan BKKBN provinsi maupun SKPD KB kabupaten/kota.

\section{Jumlah Fasilitas Kesehatan Terdaftar dalam K/O/KB yang Sudah Bekerja sama dengan BPJS Kesehatan}

Salah satu tugas dan tanggung jawab yang tercantum dalam perjanjian kerjasama antara BKKBN dan BPJS Kesehatan adalah saling tukar informasi mengenai data Faskes. Tindak lanjut yang belum maksimal menyebabkan data Faskes yang terdaftar dalam K/0/KB (Faskes KB) dengan Faskes yang bekerja sama dengan BPJS Kesehatan tidak terjadi sinkronisasi (Tabel 2 dan Tabel 3). Hal ini menunjukkan jumlah dan nama antara data Faskes KB dengan data Faskes yang bekerja sama dengan BPJS Kesehatan tidak sama.

Tabel 2 menunjukkan Faskes pemerintah dan Faskes swasta yang terdaftar dalam K/0/KB BKKBN (Faskes KB) bekerja sama dengan
BPJS Kesehatan. Faskes pemerintah di era JKN secara otomatis bekerja sama dengan BPJS Kesehatan, tetapi data Faskes KBBKKBN menunjukkan ada Faskes Pemerintah yang tidak bekerja sama dengan BPJS Kesehatan. Hal ini disebabkan diantaranya kesalahan dalam pemasukan data, sebagai contoh Faskes swasta dimasukan ke Faskes pemerintah dan Pustu yang merupakan jejaring dari Fasilitas Kesehatan Tingkat Pertama (FKTP) dimasukan ke dalam data $\mathrm{K} / \mathrm{O} / \mathrm{KB}$. Sementara itu, bagi Faskes swasta yang terdaftar dalam K/0/KB-BKKBN namun tidak bekerja sama dengan BPJS Kesehatan salah satu penyebabnya adalah bidan yang merupakan jejaring dari FKTP didaftarkan dalam $\mathrm{K} / 0 / \mathrm{KB}$ dan Faskes yang terdaftar dalam K/O/KB memang tidak mau bekerja sama dengan BPJS Kesehatan dengan berbagai alasan. Beberapa alasan Faskes yang tidak mau bekerja sama dengan BPJS Kesehatan antara lain adalah besarnya klaim tidak sesuai dengan besarnya rupiah yang dikeluarkan untuk memenuhi persyaratan pengajukan klaim, prose klaim yang rumit, lama pencairan klaim, persepsi adanya pemotongan dana klaim, dan persyaratan untuk bekerja sama yang rumit.

\section{Jumlah Fasilitas Kesehatan yang Bekerja Sama dengan BPJS Kesehatan yang Terdaftar dalam K/O/KB}

Tabel 3 merupakan kebalikan dari Tabel 2 yaitu menunjukkan Faskes yang bekerja sama dengan BPJS Kesehatan dan terdaftar dalam K/0/KB-BKKBN (Faskes KB), baik Faskes Pemerintah maupun Faskes Swasta. Bagi Faskes yang bekerja sama dengan BPJS Kesehatan, tetapi tidak terdaftar dalam K/O/KB-BKKBN merupakan Faskes yang berpotensi untuk diregister, dengan syarat Faskes tersebut memberikan pelayanan KB.

\section{Pengetahuan dan kepesertaan masyarakat dalam layanan BPJS Kesehatan}

Pengetahuan terhadap JKN. Pengetahuan masyarakat tentang JKN merupakan faktor utama bagi masyarakat untuk ikut atau tidak menjadi peserta BPJS Kesehatan. Hasil penelitian menunjukkan bahwa pengetahuan tentang JKN pada responden relatif tinggi (93,3\%). Responden mengetahui JKN melalui berbagai sumber informasi, yaitu media masa ( $T V$, radio, media cetak), forum pertemuan (PKK, Posyandu), dan sumber lainnya (keluarga, teman, tetangga). Selanjutnya, sumber informasi JKN tertinggi dari TV $(94,6 \%)$. 
Tabel 2 Faskes yang Terdaftar dalam K/O/KB-BKKBN Bekerja sama dengan BPJS Kesehatan

\begin{tabular}{|c|c|c|c|c|c|c|c|c|c|c|c|c|}
\hline \multirow{3}{*}{ Kabupaten/Kota } & \multicolumn{6}{|c|}{ Faskes Pemerintah } & \multicolumn{6}{|c|}{ Faskes Swasta } \\
\hline & \multicolumn{2}{|c|}{ Ya } & \multicolumn{2}{|c|}{ Tdk } & \multicolumn{2}{|c|}{ Total } & \multicolumn{2}{|c|}{ Ya } & \multicolumn{2}{|c|}{ Tdk } & \multicolumn{2}{|c|}{ Total } \\
\hline & $\mathrm{n}$ & $\%$ & $\mathrm{n}$ & $\%$ & $\mathrm{n}$ & $\%$ & $\mathrm{n}$ & $\%$ & $\mathrm{n}$ & $\%$ & $\mathrm{n}$ & $\%$ \\
\hline Lampung & & & & & & & & & & & & \\
\hline Kota & 35 & 97,2 & 1 & 2,8 & 36 & 100,0 & 8 & 53,3 & 7 & 46,7 & 15 & 100,0 \\
\hline $\begin{array}{l}\text { Kab. Pesawaran } \\
\text { Jawa Barat }\end{array}$ & 13 & 30,9 & 29 & 69,1 & 42 & 100,0 & & & 2 & 66,7 & 3 & 100,0 \\
\hline Kota E & 76 & 86,4 & 12 & 13,6 & 88 & 100,0 & 7 & 15,2 & 39 & 84,8 & 46 & 100,0 \\
\hline Kab. P & 20 & 40 & 30 & 60 & 50 & 100 & 1 & 1 & 68 & 98,5 & 69 & 100,0 \\
\hline & & 22,2 & 42 & 77,8 & 54 & 100,0 & & 0,0 & 67 & 100,0 & 67 & 100,0 \\
\hline $\begin{array}{l}\text { Kab. Pulang Pisau } \\
\text { Nusa Tenggara Timur }\end{array}$ & 10 & 19,6 & 41 & 80,4 & 51 & 100,0 & 0 & 0,0 & 0 & 0,0 & 0 & 0,0 \\
\hline Kota I & & 63 & 8 & 36,4 & & 100 & & 19,1 & 17 & & 21 & 100,0 \\
\hline Kab. Kupang & 24 & 92,3 & 2 & 7,7 & 26 & 100,0 & & 0,0 & 1 & 100,0 & 1 & 100,0 \\
\hline
\end{tabular}

Hasil penelitian Komariah (2015a) di Kota Balikpapan ditemukan bahwa masyarakat memperoleh informasi mengenai JKN dari berbagai sumber antara lain petugas BPJS Kesehatan, media cetak dan elektronik seperti leaflet, majalah, koran, televisi, dan radio. Sosialisasi yang dilakukan oleh petugas BPJS Kesehatan menggunakan dua cara komunikasi yaitu interpersonal dan kelompok. Komunikasi interpersonal dilakukan melalui komunikasi langsung pada masyarakat di Kantor BPJS Kesehatan. Sementara itu, komunikasi kelompok dilakukan dengan cara mengadakan seminar kepada para pegawai perusahaan swasta, pemerintah, dan lembaga organisasi.

Kepesertaan dalam JKN. Peraturan Presiden RI Nomor 12 Tahun 2013 menyebutkan bahwa peserta JKN adalah setiap orang, termasuk orang asing yang bekerja paling singkat enam bulan di Indonesia yang telah membayar iuran, meliputi: 1) Penerima Bantuan Iuran (PBI) jaminan kesehatan yaitu fakir miskin dan orang tidak mampu yang tidak memiliki kemampuan membayar iuran bagi dirinya dan anggota keluarganya dan penetapan peserta PBI ditentukan oleh pemerintah dan 2) Bukan
Penerima Bantuan luran (Bukan PBI). Hasil penelitian menunjukkan bahwa secara total dari 240 jumlah responden di empat provinsi, hanya 28,3 persen responden yang mempunyai kartu BPJS Kesehatan. Dari delapan kabupaten/kota lokasi penelitian, kepemilikan kartu BPJS Kesehatan tertinggi berada di Kota Kupang (73,3\%), diikuti oleh Kota Palangka Raya $(43,3 \%)$ dan Kabupaten Kupang (40,0\%). Menurut Nurhasana (2015), ada beberapa motif masyarakat untuk menjadi peserta BPJS Kesehatan yaitu faktor sosial dan teman sebaya, faktor budaya, faktor ekonomi, dan faktor keamanan masa depan.

\begin{abstract}
Alasan Tidak Menjadi Peserta BPJS Kesehatan. Ada beberapa alasan keluarga responden tidak menjadi peserta BPJS Kesehatan yaitu belum pernah mendengar, belum sempat mengurus, tidak tahu prosedur mendaftarnya, persyaratan belum lengkap, sudah punya kartu/asuransi lainnya, dan mahal atau tidak dapat membayar. Hasil penelitian menunjukkan alasan tertinggi $(46,5 \%)$ tidak menjadi peserta BPJS Kesehatan adalah karena sudah punya kartu asuransi lainnya.
\end{abstract}

Tabel 3 Faskes bekerja sama dengan BPJS Kesehatan terdaftar dalam K/0/KB-BKKBN

\begin{tabular}{|c|c|c|c|c|c|c|c|c|c|c|c|c|}
\hline \multirow{3}{*}{ Kab./Kota } & \multicolumn{6}{|c|}{ Faskes Pemerintah } & \multicolumn{6}{|c|}{ Faskes Swasta } \\
\hline & \multicolumn{2}{|c|}{$\mathrm{Ya}$} & \multicolumn{2}{|c|}{ Tidak } & \multicolumn{2}{|c|}{ Total } & \multicolumn{2}{|c|}{$\mathrm{Ya}$} & \multicolumn{2}{|c|}{ Tidak } & \multicolumn{2}{|c|}{ Total } \\
\hline & $\mathrm{n}$ & $\%$ & $\mathrm{n}$ & $\%$ & $\mathrm{n}$ & $\%$ & $\mathrm{n}$ & $\%$ & $\mathrm{n}$ & $\%$ & $\mathrm{n}$ & $\%$ \\
\hline Lampung & & & & & & & & & & & & \\
\hline Kota Bandar Lampung & 35 & 87,5 & 5 & 12,5 & 40 & 100,0 & 8 & 14,5 & 47 & 85,5 & 55 & 100,0 \\
\hline $\begin{array}{l}\text { Kab. Pesawaran } \\
\text { Jawa Barat }\end{array}$ & 13 & 86,7 & 2 & 13,3 & 15 & 100,0 & 1 & 11,1 & 8 & 88,9 & 9 & 100,0 \\
\hline Kota Bandung & 76 & 81,7 & 17 & 18,3 & 93 & 100,0 & 7 & 7,2 & 90 & 92,8 & 97 & 100,0 \\
\hline $\begin{array}{l}\text { Kab. Purwakarta } \\
\text { Kalimantan Tengah }\end{array}$ & 20 & 83,3 & 4 & 16,7 & 24 & 100,0 & 1 & 2,3 & 43 & 97,7 & 44 & 100,0 \\
\hline Kota Palangka Raya & 12 & 60,0 & 8 & 40,0 & 20 & 100,0 & 0 & 0,0 & 12 & 100,0 & 12 & 100,0 \\
\hline $\begin{array}{l}\text { Kab. Pulang Pisau } \\
\text { Nusa Tenggara Timur }\end{array}$ & 10 & 71,4 & 4 & 28,6 & 14 & 100,0 & 0 & 0,0 & 1 & 100,0 & 1 & 100,0 \\
\hline Kota Kupang & 14 & 63,6 & 8 & 36,4 & 22 & 100,0 & 3 & 11,5 & 23 & 88,5 & 26 & 100,0 \\
\hline Kab. Kupang & 24 & 70,6 & 10 & 29,4 & 34 & 100,0 & 0 & 0,0 & 0 & 0,0 & 0 & 0,0 \\
\hline
\end{tabular}


Kartu asuransi yang dimaksud adalah adalah kartu Jamkesmas dan Jamkesda yang fungsinya sama seperti kartu BPJS Kesehatan. Hasil penelitian oleh Yandrizal et al. (2015) di Kota Bengkulu ditemukan bahwa, masyarakat yang belum menjadi peserta JKN sebagian besar dari keluarga tidak mampu.

Cara Memperoleh Kartu BPJS Kesehatan. Cara memperoleh kartu BPJS Kesehatan dapat diperoleh dengan 3 cara. Cara pertama adalah mengurus sendiri, jika dirinya memahami prosedur untuk membuat kartu dan mempunyai waktu dalam mengurus kartu. Cara kedua yaitu dengan diurus orang lain, bisa melalui perantara seperti keluarga, saudara, tetangga maupun perangkat $R T, R W$, maupun desa/kelurahan. Selanjutnya cara ketiga yaitu dengan memperoleh secara otomatis, biasanya adalah peserta penerima bantuan iuran atau yang lebih dikenal sebagai peserta Penerima Bantuan luran (PBI). Hasil penelitian menunjukkan bahwa, cara memperoleh kartu BPJS Kesehatan tertinggi $(39,7 \%)$ diperoleh secara otomatis.

Pembayaran Kepesertaan BPJS Kesehatan. Sudah dijelaskan sebelumnya bahwa peserta BPJS Kesehatan terbagi menjadi 2 yaitu: 1) peserta Penerima Bantuan luran (PBI), peserta ini tidak membayar untuk menjadi peserta, 2) peserta bukan PBI yaitu peserta yang cara pembayaran dipotong gaji atau dapat juga dengan membayar sendiri/peserta mandiri. Hasil penelitian menunjukkan bahwa dari 68 responden yang menjadi peserta BPJS Kesehatan, sebesar 52,9 persen merupakan peserta yang membayar.

Bagi masyarakat yang membayar untuk menjadi peserta JKN, ada 3 kelas yang ditawarkan oleh BPJS kesehatan yaitu: untuk Kelas I dengan tarif Rp59.500, Kelas II dengan tarif Rp42.500, dan kelas III dengan tarif Rp25.500. Hasil penelitian menunjukkan bahwa, dari 32 orang responden yang membayar untuk menjadi peserta JKN, sebagian besar $(53,1 \%)$ membayar sebesar Rp25.500/bulan yaitu untuk kelas III. Sebanyak 34,4 persen responden memilih iuran Rp42.500/bulan (kelas II) dan lainnya (12,5\%) memilih iuran sebesar Rp59.500/bulan (kelas I). Tarif atau premi BPJS kesehatan sangat murah jika dibandingkan dengan asuransi swasta (Dewi \& Sulistyani, 2015). Hasil penelitian yang dilakukan oleh Purwandari \& Maharani (2015) yang melakukan penelitian dengan menggunakan responden pekerja yang bukan merupakan $\mathrm{PBI}$ yang belum terdaftar program JKN di Kabupaten Brebes menunjukkan bahwa, responden sebagian besar setuju dengan tarif yang dikeluarkan oleh BPJS Kesehatan sesuai dengan mutu pelayanan rawat inap yang diperoleh.

Pemanfaatan Kartu BPJS Kesehatan. Tidak semua responden yang mempunyai kartu BPJS Kesehatan memanfaatkan kartu tersebut. Hasil penelitian menunjukkan bahwa, sebagian besar $(70,6 \%)$ responden yang mempunyai kartu BPJS Kesehatan memanfaatkan kartu tersebut. Pemanfaatan kartu BPJS Kesehatan tertinggi (85,4\%) digunakan untuk periksa kesehatan. Hasil penelitian yang dilakukan oleh Rumengan et al., (2015) dengan responden peserta BPJS Kesehatan penerima bantuan iuran di Kecamatan Mapanget menunjukkan bahwa, keluarga yang mempunyai persepsi baik tentang JKN maka keluarga tersebut mempunyai peluang lebih besar untuk memanfaatkan kartu BPJS Kesehatan dibandingkan keluarga yang mempunyai persepsi kurang baik tentang JKN. Sementara itu, keluarga yang mempunyai persepsi baik terhadap tindakan petugas kesehatan maka keluarga tersebut mempunyai peluang lebih besar untuk memanfaatkan kartu BPJS Kesehatan dibandingkan keluarga yang mempunyai persepsi kurang baik terhadap tindakan petugas kesehatan. $\begin{array}{lcc}\begin{array}{l}\text { Keuntungan } \\ \text { Kesehatan. }\end{array} & \text { menjadi Peserta } & \text { BPJS } \\ \text { menyebutkanmenjadi } & \text { peserta } & (2015) \\ \text { BPJS }\end{array}$ Kesehatan dapat meringankan beban biaya masyarakat dalam memperoleh kesehatan. Hasil penelitian menunjukkan bahwa dari 68 responden di 4 (empat) provinsi yang mempunyai kartu BPJS Kesehatan menyatakan beberapa keuntungan di antaranya: periksa kesehatan lebih mudah $(83,8 \%)$, periksa kesehatan lebih murah $(94,1 \%)$, periksa kesehatan lebih cepat $(75,0 \%)$, periksa kehamilan lebih mudah $(67,7 \%)$, periksa kehamilan lebih murah $(76,5 \%)$, periksa kehamilan lebih cepat $(66,2 \%)$, dan biaya melahirkan gratis $(73,5 \%)$. Responden juga menyatakan bahwa, keuntungan menjadi peserta BPJS Kesehatan khusus terkait pelayanan KB adalah penggunaan kontrasepsi gratis dan biaya efek samping penggunaan kontrasepsi gratis.

Permasalahan menjadi Peserta BPJS Kesehatan. Selain mendapat keuntungan, saat menjadi peserta BPJS Kesehatan, responden juga mempunyai permasalahan saat menjadi peserta BPJS Kesehatan. Terdapat 13,2 persen dari 68 responden yang 
mempunyai kartu BPJS Kesehatan, yang mempunyai permasalahan. Permasalahan tersebut antara lain lama dilayani, hanya dilayani pada Faskes tertentu, jenis pelayanannya terbatas dan waktu pelayanannya terbatas. Permasalahan khusus terkait pelayanan $\mathrm{KB}$ adalah jenis obat termasuk alkon terbatas, kualitas termasuk alkon tidak sesuai dengan yang diinginkan. Hasil penelitian yang dilakukan oleh Putri (2014) dan Chandra \& Utami (2016) menemukan bahwa pelayanan di fasilitas kesehatan tertentu cenderung berbelit-belit, petugas kurang cekatan, petugas kurang ramah (menunjukkan mimik wajah tidak suka, kadang memarahi, dan kurang bersimpati), terutama kepada pasien peserta $\mathrm{PBI}$ sehingga masyarakat miskin merasa diabaikan oleh pemerintah.

\section{PEMBAHASAN}

Komitmen pemerintah dalam pelaksanaan program asuransi sosial kesehatan untuk keluarga miskin yang dikemas dalam program Jaminan Kesehatan Masyarakat (Jamkesmas) yang dilaksanakan sejak tahun 2005 mulai memasuki babak baru. Sejak 1 Januari 2014 Pemerintah Indonesia meluncurkan program Jaminan Kesehatan Nasional (JKN) yang bertujuan untuk memberikan perlindungan kesejahteraan bagi masyarakat Indonesia dari guncangan kesehatan dan resiko finansial dengan menggunakan sistem pembiayaan kesehatan pra upaya (prepaid system).

JKN secara bertahap direncanakan sebagai jaminan kesehatan semesta (Universal Health Coverage) bagi seluruh penduduk Indonesia pada tahun 2019 (TNP2K, 2015; Yuliansyah et al., 2016). Keberhasilan pembiayaan kesehatan dalam konsep UHC (Universal Health Coverage) didapatkan dari Thailand. Pada tahun 1991, dua pertiga dari penduduk Thailand tidak memiliki asuransi kesehatan. Namun, pada tahun 2000, hanya 20,3 persen dari penduduk Thailand yang tidak diasuransikan. Setelah diberlakukannya Universal Health Coverage (UHC), angka ini turun menjadi kurang dari 4,0 persen (Primasari, 2015).

Manfaat Jaminan Kesehatan Nasional (JKN) mencakup pelayanan promotif, preventif, kuratif, dan rehabilitasi termasuk pelayanan obat dan bahan medis habis pakai sesuai dengan kebutuhan medis. Keluarga Berencana (KB) merupakan salah satu bagian dari manfaat pelayanan promotif dan preventif, selain penyuluhan kesehatan perorangan, imunisasi dasar, dan skrining kesehatan. Pelayanan Keluarga Berencana meliputi konseling, kontrasepsi dasar, vasektomi, dan tubektomi yang pelaksanaannya dilakukan oleh BPJS Kesehatan bekerja sama dengan lembaga yang membidangi Keluarga Berencana yaitu BKKBN dan SKPD KB di tingkat kabupaten/kota.

Institusi penyelenggara pelayanan KB dalam JKN terdiri dari BPJS Kesehatan, Kementerian Kesehatan, dan BKKBN. Berdasarkan peran dan fungsinya BPJS Kesehatan bergerak pada demand side (akses jaminan), sedangkan Kementerian Kesehatan dan BKKBN pada supply side (penyedia tenaga kesehatan dan alat kontrasepsi). Kesiapan institusi penyelenggara pelayanan KB dalam JKN dapat dilihat dari tindak lanjut perjanjian kerjasama antara BKKBN dan BPJS Kesehatan Nomor 83/KSM/G2/2014 dan Nomor 0199/KTR/0314 tentang Pedoman Penyelenggaraan Pelayanan KB dalam JKN. Selain itu, kesiapan institusi penyelenggara pelayanan $\mathrm{KB}$ dalam JKN dapat dilihat dengan terbentuknya Kelompok Kerja (POKJA) KB dalam JKN dari tingkat pusat sampai keluarahan/desa.

Secara umum, kesiapan institusi untuk melaksanakan pelayanan KB dalam JKN belum maksimal. Tindak lanjut mengenai perjanjian kerjasama antara BKKBN dan BPJS Kesehatan baru sebatas sosialisasi dan identifikasi Faskes KB yang bekerja sama dengan BPJS Kesehatan. Perwakilan BKKBN Provinsi belum semua menindaklanjuti perjanjian kerjasama antara BKKBN dengan BPJS Kesehatan tentang penyelenggaraan pelayanan KB dalam JKN, begitu juga dengan SKPD KB kabupaten/kota. Bahkan ada yang belum tahu adanya perjanjian kerjasama tersebut. Selain itu, semua wilayah penelitian belum terbentuk kelompok kerja (POKJA) KB dalam JKN bahkan buku pedoman penyelenggaraan pelayanan KB dalam JKN belum dimiliki oleh semua perwakilan BKKBN provinsi maupun SKPD KB kabupaten/kota. Kesiapan yang belum baik ini mengakibatkan koordinasi antarinstansi belum maksimal dan sosialisasi pelayanan KB dalam JKN masih rendah.

Faskes yang terdaftar dalam K/0/KB-BKKBN (Faskes KB) tidak semuanya dapat bekerja sama dengan BPJS Kesehatan. Hal ini disebabkan ada proses kredensialing dan rekredensialing dari BPJS Kesehatan bagi Faskes yang ingin bekerja sama. Adanya perbedaaan sistem informasi faskes antara 
BKKBN dan BPJS Kesehatan menyebabkan bagi Faskes yang terdaftar dalam K/0/KB BKKBN atau tercatat sebagai Faskes KB, Faskes tersebut mendapat distribusi Alkon dari BKKBN tetapi jika tidak bekerja sama dengan BPJS Kesehatan maka Faskes tersebut tidak memperoleh dana pelayanan KB dari BPJS Kesehatan. Sebaliknya, bagi Faskes yang bekerja sama dengan BPJS Kesehatan tetapi tidak terdaftar dalam K/O/KB BKKBN maka Faskes tersebut memperoleh pembiayaan pelayanan KB tetapi tidak memperoleh distribusi Alkon gratis dari BKKBN.

Kebijakan pemerintah tentang Jaminan Kesehatan Nasional (JKN) perlu diketahui dan dipahami oleh seluruh masyarakat Indonesia. Sosialisasi tentang JKN sangat diperlukan masyarakat karena akan membuat masyarakat mengetahui hak dan kewajiban mereka sebagai peserta BPJS Kesehatan serta dapat memanfaatksn kartu BPJS Kesehatan dengan baik dan benar (Rismawati, 2015). Hasil penelitian menunjukkan bahwa, pengetahuan masyarakat tentang Jaminan Kesehatan Nasional (JKN) relatif tinggi, tetapi tidak semua responden yang mempunyai kartu BPJS Kesehatan memanfaatkan kartu tersebut. Sejalan dengan penelitian Witcahyo (2016), ditemukan bahwa meskipun sebagian besar masyarakat telah mendengar JKN, namun informasi yang mereka dapatkan masih terbatas. Hal tersebut berdampak pada ketidakyakinan mereka untuk mengikuti JKN. Hasil ini sejalan juga dengan penelitian Midi \& Damayanti (2014) yang menemukan bahwa tingkat pengetahuan pada peserta program JKN relatif tinggi, yaitu 95,7 persen. Sementara, bukan peserta sebanyak 55,6 persen yang mengetahui program JKN.

Menurut Widhiastuti et al. (2015), untuk meningkatkan kepesertaan JKN secara mandiri, diperlukan edukasi kepada masyarakat dengan pesan-pesan yang lebih spesifik terutama berkaitan dengan besarnya risiko untuk mengalami suatu penyakit dan mahalnya biaya pengobatan. Pemanfaatan kartu BPJS Kesehatan terutama digunakan untuk memeriksakan kesehatan, sedangkan pemanfaatan kartu untuk penggunaan kontrasepsi relatif rendah. Rendahnya pemanfaatan kartu BPJS Kesehatan untuk penggunaan kontrasepsi disebabkan sosialisasi pelayanan KB dalam JKN masih kurang. Sebagian masyarakat tidak tahu bahwa kartu BPJS Kesehatan dapat dimanfaatkan untuk pelayanan KB. Ketidaktahuan masyarakat khususnya keluarga miskin Penerima Bantuan luran (PBI) yang iurannya dibayarkan oleh pemerintah, dapat mengakibatkan masyarakat tidak menggunakan kontrasepsi karena alasan tidak sanggup membayar.

Temuan pada penelitian ini menyebutkan bahwa salah satu alasan tidak menjadi peserta BPJS Kesehatan, yaitu mahal atau tidak dapat membayar. Hasil ini sejalan dengan penelitian Komariah (2015b) yang menemukan bahwa banyak masyarakat tidak mampu yang mengeluhkan pelayanan kesehatan ini karena ada aturan bahwa iuran jaminan kesehatan ini merupakan sejumlah uang yang dibayarkan secara teratur oleh peserta dan apabila terlambat membayar maka akan dikenakan denda $2 \%$ per bulan. Oleh karena itu, masih banyak masyarakat tidak mampu yang belum ikut berpartisipasi dalam kepesertaan JKN BPJS Kesehatan.

Penelitian ini memiliki keterbatasan yaitu hanya menggunakan responden keluarga dari pihak istri saja, akan lebih lengkap jika suami ikut serta sebagai responden sehingga dapat dibandingkan antara pengetahuan dan kepesertaan dalam layanan BPJS Kesehatan dari sudut pandang istri maupun suami.

\section{SIMPULAN DAN SARAN}

Kesiapan institusi untuk melaksanakan pelayanan KB dalam JKN belum maksimal. Perwakilan BKKBN provinsi belum semua menindaklanjuti perjanjian kerja sama antara BKKBN dengan BPJS Kesehatan tentang penyelenggaraan pelayanan KB dalam JKN, begitu juga dengan SKPD KB kabupaten/kota. Bahkan ada yang belum tahu adanya perjanjian kerjasama tersebut. Selain itu, di semua wilayah penelitian belum membentuk kelompok kerja (POKJA) KB dalam JKN. Kesiapan yang belum baik ini mengakibatkan koordinasi antarinstansi belum maksimal, sosialisasi pelayanan KB dalam JKN masih rendah, dan data Faskes yang terdaftar dalam $\mathrm{K} / \mathrm{O} / \mathrm{KB}$ (Klinik KB) dengan Faskes yang bekerja sama dengan BPJS Kesehatan tidak terjadi sinkronisasi.

Pengetahuan masyarakat tentang JKN relatif tinggi, tetapi kepemilikan kartu BPJS Kesehatan masih rendah. Pada responden yang memiliki kartu BPJS Kesehatan, lebih dari setengahnya merupakan peserta yang membayar dan tidak semua masyarakat yang memiliki kartu BPJS Kesehatan memanfaatkannya. Pemanfaatan kartu BPJS Kesehatan lebih banyak digunakan untuk memeriksakan kesehatan, kehamilan, dan 
kelahiran dibandingkan untuk pemakaian kontrasepsi dan efek samping penggunaan kontrasepsi.

Berdasarkan hasil penelitian tersebut maka disarankan pemerintah dalam hal ini BKKBN untuk berkoordinasi dengan Dinas Kesehatan dan BPJS Kesehatan melakukan sosialisasi bahwa KB atau penggunaan alat/cara dan obat kontrasepsi merupakan bagian dari manfaat promotif dan preventif JKN, dengan sasaran seluruh provider (bidan dan dokter) pemberi pelayanan KB dan masyarakat. Perwakilan BKKBN provinsi maupun SKPD KB kabupaten/kota diharapkan selalu melakukan up date data tentang Faskes yang terdaftar dalam K/0/KB, memetakan data Faskes yang teregiter dalam K/0/KB yang sudah maupun tidak bekerja sama dengan BPJS Kesehatan, kemudian melakukan sinkronisasi data Faskes yang terdaftar dalam K/0/KB dengan Faskes yang sudah bekerja sama dengan BPJS Kesehatan melalui penyesuaian nama dan kode Faskes sesuai yang ada di Kementerian Kesehatan. Selain itu, keluarga juga diharapkan mencari informasi secara aktif mengenai fasilitas yang diberikan oleh BPJS Kesehatan.

\section{DAFTAR PUSTAKA}

Amalina, R., Respati, T., Budiman. (2015). Tingkat pengetahuan jaminan kesehatan nasional peserta badan penyelenggara jaminan sosial kesehatan di Puskesmas Plered Kabupaten Purwakarta tahun 2015. Prosiding Pendidikan Dokter, 02 , 1086-1091.

Chandra, B.S.S., Utami, D. (2016). Interaksi simbolik keluarga pasien miskin pengguna JKN dan NAKES di Rumah Sakit Umum Daerah Sarifah Ambami Rato Ebu Bangkalan. Paradigma, 4(1): 1-6.

Dewi, M. W., Sulistyani, D. (2015). Perbandingan premi asuransi kesehatan peserta BPJS Badan Usaha dengan Asuransi Kesehatan Swasta. Jurnal Akuntansi dan Pajak, 16(1), 33-47.

Djunawan, A., Haksama, S. (2015). Hubungan kerjasama, motivasi, sikap dan kinerja Bidan dalam pelayanan antenatal. Jurnal Administrasi Kesehatan Indonesia, 3(1): 11-20.

Endartiwi, S.S. (2015). Indikasi adverse selection pada peserta non PBI mandiri Jaminan Kesehatan Nasional (JKN) di
RS Rajawali Citra Bantul Yogyakarta. Jurnal Kebidanan dan Keperawatan, 11(2): 158-167.

Hartati, W. (2015). Kajian yuridis perubahan PT. Askes (PERSERO) menjadi Badan Penyelenggara Jaminan Sosial (BPJS) Kesehatan. Jurnal IUS, 3(9): 481-496.

Komariah, S. (2015a). Perencanaan komunikasi Badan Penyelenggara Jaminan Sosial (BPJS) Kota Balikpapan dalam mensosialisasikan Program Jaminan Kesehatan Nasional (JKN) kepada masyarakat Kota Balikpapan. Ejournal IImu Komunikasi, 3(2), 107121.

(2015b). Fungsi Badan Penyelenggara Jaminan Sosial (BPJS) terhadap Jaminan Kesehatan masyarakat di Desa Kapur Kecamatan Sungai Raya. Sociodev, 04, 1-18.

Midi, R. D. A. A. C., Damayanti, N. A. (2014). Kesiapan masyarakat tentang program Jaminan Kesehatan Nasional di wilayah kerja Puskesmas Banyuanyar Sampang. Jurnal Administrasi Kesehatan Indonesia, 02, 83-90.

Nurhasana, R. (2015). Motif kepesertaan dan partisipasi pembayaran iuran peserta perorangan dalam Jaminan Kesehatan Nasional (JKN): Studi kasus di Kelurahan Lenteng Agung Jakarta Selatan. Jurnal Kedokteran dan Kesehatan, 11(1), 94-106.

Prakoso, S. B. (2015). Efektivitas pelayanan kesehatan BPJS di Puskesmas Kecamatan Batang. EDAJ, 4(1), 72-80.

Primasari, K. L. (2015). Analisis sistem rujukan jaminan kesehatan nasional RSUD Dr Adjidarmo Kabupaten Lebak. ARSI, 1(2), 78-86.

Purwandari, S. I., Maharani, C. (2015). Analisis sikap pekerja informal non $\mathrm{PBI}$ yang belum terdaftar program Jaminan Kesehatan Nasional (JKN) 2014 di Kabupaten Brebes. UJPH, 4(2), 84-91.

Putri, N. E. (2014). Efektivitas penerapan jaminan kesehatan nasional Melalui BPJS dalam pelayanan kesehatan masyarakat miskin di Kota Padang. TINGKAP, 10(2), 175- 189.

Rismawati. (2015). Pelayanan BPJS kesehatan masyarakat di Puskesmas Karang Asam Kecamatan Sungai Kunjang Kota Samarinda. Ejournal IImu Administrasi Negara, 3(5), 1668-1682. 
Rumengan, D. S. S., Umboh, J. M. L., Kandou, G. D. (2015). Faktor-faktor yang berhubungan dengan pemanfaatan pelayanan kesehatan pada peserta BPJS kesehatan di Puskesmas Paniki Bawah Kecamatan Mapanget Kota Manado. JIKMU, 5(1), 88-100.

Sastradimulya, F., Nurhayati, E., Susanti, Y. (2015). Hubungan tingkat pengetahuan pasien tentang Jaminan Kesehatan Nasional dengan status kepesertaan BPJS. Prosiding Pendidikan Dokter, 02, 578-583.

[TNP2K]. Tim Nasional Percepatan Penanggulangan Kemiskinan. (2015). Perjalanan menuju Jaminan Kesehatan Nasional (JKN). Jakarta, ID: TNP2K.

Widhiastuti, I.A.P., Januraga, P.P., \& Wirawan, D.N. (2015). Hubungan persepsi manfaat dengan kepesertaan JKN secara mandiri di Puskesmas I Denpasar Timur. Public Health and Preventive Medicine Archive, 3(2): 203210.
Witcahyo, E. (2016). Kesiapan dan persepsi masyarakat Kabupaten Bondowoso terhadap kebijakan Jaminan Kesehatan Nasional (JKN). E-Jurnal Pustaka Kesehatan, 4(1): 188-195.

Yandrizal, Suryani, D. (2015). Analisis peran pemerintah daerah terhadap ketersediaan fasilitas kesehatan pada pelaksanaan jaminan kesehatan nasional di Provinsi Bengkulu. Jurnal Kesehatan Andalas, 4(1): 107-114.

Yandrizal, Rifa'i., Utami, S.P. (2015). Analisis kemampuan dan kemauan membayar iuran terhadap pencapaian UHC JKN di Kota Bengkulu. Jurnal Kesehatan Andalas, 10(1): 3-10.

Yuliansyah, M.A., Nuryadi, Herawati, Y.T. (2016). Analisis stakeholder dalam kebijakan pemenuhan fasilitas kesehatan tingkat pertama pada program jaminan kesehatan nasional di Kabupaten Jember. E-Jurnal Pustaka Kesehatan, 4(1): 152-159. 